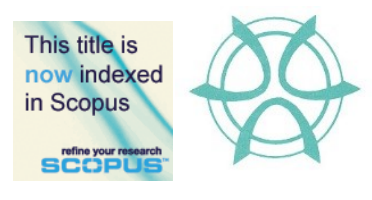

PLANNING MALAYSIA:

Journal of the Malaysian Institute of Planners

VOLUME 19 ISSUE 5 (2021), Page 66 - 75

\title{
KINABALU NATIONAL PARK, UNESCO WORLD HERITAGE SITE: ASSESSMENT OF ENVIRONMENTAL ISSUES, TOURIST SATISFACTION AND PARK MANAGEMENT
}

\author{
Normah Abdul Latip ${ }^{1}$, Rehmat Karim ${ }^{2}$, Mastura Jaafar ${ }^{3}$, Azizan Marzuki ${ }^{4}$, A. \\ Ghafar Ahmad ${ }^{5}$, Sharifah Zahhura Syed Abdullah ${ }^{6}$, Mohd Umzarulazijo \\ Omar@Umar ${ }^{7}$ \\ 1,2,3,4,5,6,7 School of Housing Building and Planning \\ UNIVERSITI SAINS MALAYSIA
}

\begin{abstract}
National parks serve as rural ecotourism attractions, the management of which must strike a balance between economic productivity and the protection of the park's natural value. Faced with the increased pressure of rising visitor numbers park management must give greater consideration to the tourist experience and tourist satisfaction. This paper examines the relationship between park management, tourist satisfaction, and environmental issues. Moreover, this paper considers the mediating role of environmental issues on the relationship between park management and tourist satisfaction. A questionnaire survey was administered to visitors of Malaysia's Kinabalu National Park. In total, 351 completed questionnaires were returned and Partial Least Squares-Structural Equation Modelling (PLS-SEM) was used to analyze the resultant data using SmartPLS 2.0. The results showed that park management has a strong effect on tourist satisfaction and environmental issues. The results also revealed that environmental issues play a mediating role in the relationship between park management and tourist satisfaction.
\end{abstract}

Keywords: Park management, environmental issues, tourist satisfaction, Kinabalu National Park

\footnotetext{
${ }^{1}$ Senior Lecturer at Universiti Sains Malaysia Email: norma_abdlatip@usm.my
} 
PLANNING MALAYSIA

Journal of the Malaysia Institute of Planners (2021)

\section{INTRODUCTION}

Tourism is a significant contributor to the Malaysian economy, and the Malaysian government is committed to supporting the growth of the tourism industry. However, the rapid growth of the Malaysian tourism sector has come at the cost of the increased use of the nation's natural resources. Consequently, tourism resources, such as Kinabalu Park, are often adversely impacted through the overuse and exploitation of tourism destinations. Blanke and Chiesa (2013) observe that Malaysia has struggled to cope with the rising demand on its environmental resources, with Malaysia's environmental sustainability rating having dropped from 44 to 61 in 2008 according to the T\&TC report. Moreover, Malaysia's ranking on $\mathrm{CO}_{2}$ emissions has dropped from 86 in 2008 to 103 in 2013 Blanke and Chiesa (2013). Kinabalu Park was gazetted in 1964 and it is well-known for its biodiversity (Tay et al., 2016). Kinabalu is one of the oldest world heritage sites in Malaysia, after been recognized by UNESCO in 2013. The park's management, Sabah Parks, aims to promote Kinabalu Park as a nature tourism hotspot while simultaneously ensuring that the park meets world standards for sustainability and conservation. Nevertheless, the increase in the number of tourists has had an adverse impact on Kinabalu Park (Abdul et al., 2020). To this end, we argue the importance of investigating best practices in the management of Kinabalu Park, environmental conservation, and tourist satisfaction.

\section{RESEARCH BACKGROUND}

Tourism is one of the largest developing industries in the global economy, having substantial environmental, social, cultural, and economic impacts. Nevertheless, tourism development is often a double-edged sword, creating both positive (e.g., job creation and image enhancement), and negative impacts on the biophysical (e.g., water and air pollution, ecosystem degradation), and social/cultural environment (e.g., loss of culture traditions) if not well planned, developed or managed (Azam et al., 2018). Without appropriate management, tourism development can have a number of potentially harmful effects on a destination's ecosystem and environment. Rabbany et al., (2013) argue that dysfunctional or poorly managed tourism development inevitably results in the unbalanced use of natural resources, resulting in significant environmental harm. The growth of ecotourism parallels rising concerns about environmental issues in protected areas (Abdul, 2013; ; Latip et al., 2018). In fact, Rabbany et al. (2013) observes that tourism impacts every aspect of the natural and human environment, including air, water, land, built facilities, landscapes, colors, sounds, and other environmental factors. Effective Park management is critically important for achieving desirable environmental outcomes and for the long-term viability of the ecotourism industry. Bennett and Dearden (2014) argue that many national 
Normah Abdul Latip, Rehmat Karim, Mastura Jaafar, Azizan Marzuki, A. Ghafar Ahmad, Sharifah Zahhura Syed Abdullah, Mohd Umzarulazijo Omar@Umar

Kinabalu National Park, Unesco World Heritage Site: Assessment of Environmental Issues, Tourist

Satisfaction and Park Management

parks exist purely on paper, serving no real purpose other than to protect them from the extractive industries. Effective park management, however, is fundamentally about ensuring that the resources of a national park are used productively, in both quantitative and qualitative terms (Getzner, Vik, Brendehaug, \& Lane, 2014). Therefore, the investigation of tourist satisfaction is essential for ensuring sustainable park tourism management. In conclusion, efficient and systematic park management will ensure tourist satisfaction while ensuring the stability of environmental issues in Kinabalu Park. Further discussion is provided in the hypotheses of this study.

\section{RESEARCH METHODOLOGY}

This study evaluates the mediating role of environmental issues between park management and tourist satisfaction. Therefore, the research hypotheses derived from this relationship are:

H1: Park management influences tourist satisfaction in Kinabalu National Park.

H2: Park management influences environmental issues in Kinabalu National Park.

H3: Environmental issues influence tourist satisfaction in Kinabalu National Park.

H4: Environmental issues mediate the relationship between park management and tourist satisfaction in Kinabalu National Park.

This quantitative study assesses the hypothesized relationship and possible mediating effects of environmental issues between park management and tourist satisfaction within Kinabalu National Park. The method of data collection, which involved the use of a questionnaire survey, was influenced by preceding studies (Jimura, 2011), and sought to examine park management, environmental issues, and tourist satisfaction. The researcher selected respondents for this study in four parts in Kinabalu National Park, namely in Kota Belud District, Nalapak and Serinsim in Kota Marudu District, and Monggis in Ranau District. The respondents of this study included a sample of visitors to the area. This study used a simple random sampling method to obtain feedback from respondents. This method is used to minimize costs, save time, and obtain maximum accuracy and expectations that will occur in this research. The questionnaire was distributed among these visitors, with 482 questionnaires returned. Nevertheless, only 351 questionnaires were completed or deemed usable. Structural Equation Modelling (SEM) was employed to analyze the relationships between the variables. 
PLANNING MALAYSIA

Journal of the Malaysia Institute of Planners (2021)

\section{ANALYSIS AND FINDING}

The loadings of all indicators on their associated latent constructs were tested to distinguish indicator reliability. A loading more than 0.7 reveals adequate indicator reliability (Hair et al., 2011). Table 1 shows that all indicators had a loading greater than 0.7 . Two coefficients are typically considered to assess construct reliability: CR and, the more common coefficient, Cronbach's alpha (Chin, 2010).

Table 1. Result of measurement model assessment

\begin{tabular}{|c|c|c|c|c|}
\hline Construct & Items & Loading & $\mathrm{CR}$ & AVE \\
\hline \multirow[t]{8}{*}{ Park management } & & & 0.938 & 0.683 \\
\hline & $\begin{array}{l}\text { Implementing a carrying } \\
\text { capacity }\end{array}$ & 0.826 & & \\
\hline & $\begin{array}{l}\text { Establishing standards for } \\
\text { development }\end{array}$ & 0.797 & & \\
\hline & Conflict resolution strategies & 0.795 & & \\
\hline & $\begin{array}{l}\text { Increasing knowledge and } \\
\text { awareness }\end{array}$ & 0.844 & & \\
\hline & $\begin{array}{l}\text { Management of tourist } \\
\text { activities }\end{array}$ & 0.826 & & \\
\hline & Enforcing rules and regulations & 0.835 & & \\
\hline & $\begin{array}{l}\text { Establishing zoning for multiple } \\
\text { uses }\end{array}$ & 0.826 & & \\
\hline \multirow[t]{8}{*}{ Environmental issues } & & & 0.852 & 0.667 \\
\hline & $\begin{array}{l}\text { Noise pollution (vehicles, } \\
\text { visitors) }\end{array}$ & 0.712 & & \\
\hline & Air pollution (vehicles, smoke) & 0.736 & & \\
\hline & Soil erosion & 0.819 & & \\
\hline & Garbage accumulation & 0.728 & & \\
\hline & $\begin{array}{l}\text { Bad smell (garbage, toilet and } \\
\text { drainage) }\end{array}$ & 0.751 & & \\
\hline & Cleanliness of water & 0.873 & & \\
\hline & Water turbidity & 0.790 & & \\
\hline \multirow[t]{5}{*}{ Satisfaction } & & & 0.807 & 0.693 \\
\hline & $\begin{array}{l}\text { I feel I benefited from coming } \\
\text { here }\end{array}$ & 0.764 & & \\
\hline & I found the visit worthwhile & 0.703 & & \\
\hline & $\begin{array}{l}\text { The visit was as good as I had } \\
\text { hoped }\end{array}$ & 0.802 & & \\
\hline & $\begin{array}{l}\text { I would recommend this place } \\
\text { or tour to a friend }\end{array}$ & 0.793 & & \\
\hline
\end{tabular}


Normah Abdul Latip, Rehmat Karim, Mastura Jaafar, Azizan Marzuki, A. Ghafar Ahmad, Sharifah Zahhura Syed Abdullah, Mohd Umzarulazijo Omar@Umar

Kinabalu National Park, Unesco World Heritage Site: Assessment of Environmental Issues, Tourist

Satisfaction and Park Management

If I had the opportunity, I would
like to come back here again
Overall, I was satisfied with the
visit

visit

Source: Author, 2020

$\mathrm{CR}$ is the more suitable coefficient for PLS-SEM and should be greater than 0.7 (Hair et al., 2011). Table 1 indicates that the CR for both latent variables (LVs) in the measurement model was greater than 0.807. Therefore, the results demonstrate that our measurement model had internal consistency and was reliable. The validity of the reflective measurement model also accounts for convergent and discriminant validity (Hair et al., 2011). For convergent validity, LVs with an AVE greater than 0.5 were considered acceptable (Chin, 2010; Hair et al., 2011). AVE is used to measure the amount of variance in an LV as contributed by its indicators (Chin, 2010). Table 1 indicates that the AVE values for all constructs used in the measurement model were higher than 0.667 and had loadings higher than 0.7 . Therefore, the convergent validity of the measurement model was more than acceptable. Discriminant validity describes the extent to which each construct is distinct from one another (Chin, 2010). Two measures must be checked to test discriminant validity: the AVE of each construct should be higher than the highest squared correlation of the construct with any other LV in the model, and the loading of an indicator with its associated LV must be higher than its loading with other LVs (Chin, 2010; Hair et al., 2011). Table 2 shows the evaluation of the AVE of both constructs with the squared correlation of the other constructs. Table 2 reveals that the AVE of each construct is greater than the largest squared correlation of the same construct with other constructs in the model. Furthermore, the factor loadings for all items on their associated constructs was more than the cross-loading with other constructs. Consequently, the results indicate the acceptability of the reliability, convergent validity, and discriminant validity of the measurement model.

Table 2. Discriminant validity

\begin{tabular}{lccc}
\hline Constructs & Park management & $\begin{array}{l}\text { Environmental } \\
\text { issues }\end{array}$ & $\begin{array}{l}\text { Tourist } \\
\text { satisfaction }\end{array}$ \\
\hline $\begin{array}{l}\text { Park management } \\
\text { Environmental }\end{array}$ & $\mathbf{0 . 6 6 7}$ & & \\
issues & 0.205 & $\mathbf{0 . 6 8 3}$ & \\
Tourist satisfaction & 0.138 & 0.465 & $\mathbf{0 . 6 9 3}$ \\
\hline
\end{tabular}

The R-square $\left(\mathrm{R}^{2}\right)$ measure of the endogenous constructs and the path coefficients was evaluated as part of an initial examination of the structural model 
(i.e., inner model) and theoretical framework (Hair et al., 2011). Chin (2010) recommends that measures of $0.67,0.33$, and 0.19 for $\mathrm{R}^{2}$ should be thought of as respectively significant, average, and weak. The path coefficients should be substantial, and the value of $\mathrm{R}^{2}$ is contingent upon the field of study. The $\mathrm{R}^{2}$ level for the environmental issues construct in the model was 0.121 , and 0.586 for the tourist satisfaction construct. The results for the structural model assessment based on the relationship between the constructs is presented in Table 3 and Figure 2. The structural model assessment, utilizing the bootstrap process with 200,500 , and 1000 re-samplings, as well as the magnitude and significance of the structural paths are consistent. Bootstrapping resulted in 1000 samples being generated from 351 cases. To this end, Table 3 shows the positive, strong, and substantial effect of park management on environmental issues. Park management has a substantial effect on tourist satisfaction. The results indicate a positive and significant effect of environmental issues on tourist satisfaction. Tests on the mediation hypotheses (H4) use the analytical approach described by Preacher and Hayes (2008). Using this approach, we can analyze the direct effect of park management on tourist satisfaction by removing the environmental issues construct.

Table 3. The result of assessment of structural model

\begin{tabular}{lccccc}
\hline Hypotheseses & Std.Beta & SE & t-value & Supported \\
\hline H1 Park management & $\rightarrow$ & 0.266 & 0.072 & 2.460 & Yes \\
$\begin{array}{l}\text { Environmental issues } \\
\text { H2 Park management }\end{array}$ & 0.699 & 0.081 & 7.596 & Yes \\
$\begin{array}{l}\text { Tourist satisfaction } \\
\text { H3 Environmental issues }\end{array}$ & $\rightarrow 0.282$ & 0.056 & 2.554 & Yes \\
Tourist satisfaction & $\rightarrow 0.280$
\end{tabular}

Figure 4 shows the results of testing these direct effects. The application of bootstrapping (1000 re-samples) allows for testing of the mediation hypotheses (Preacher \& Hayes, 2008). In addition, Sobel (1982) describes a general procedure whereby more complicated indirect effects may be tested. The Sobel test is conducted by comparing the strength of the indirect effect of $\mathrm{X}$ on $\mathrm{Y}$ to the point null hypothesis, which equals zero (Preacher \& Hayes, 2008). The determination of significant indirect effects between two variables is decided based on the $Z$ value. The null hypothesis (there is no indirect effect between two variables) is denied whenever the $Z$ value is higher than 1.96 (Hair et al., 2011). Equation 1 is applied to identify the statistical significance of the mediation reduction. 
Normah Abdul Latip, Rehmat Karim, Mastura Jaafar, Azizan Marzuki, A. Ghafar Ahmad, Sharifah Zahhura Syed Abdullah, Mohd Umzarulazijo Omar@Umar

Kinabalu National Park, Unesco World Heritage Site: Assessment of Environmental Issues, Tourist

Satisfaction and Park Management

\begin{tabular}{|l|l|l|}
\hline & $=\frac{a b}{\sqrt{a^{2} s_{b}^{2}+b^{2} s_{a}^{2}}}$ & {$[1]$} \\
\hline
\end{tabular}

a: path coefficient value from IV to MV

b: path coefficient value from MV to DV

$s_{a}$ and $s_{b}$ : standard error values for the path coefficients

The $\mathrm{Z}$ value for this research model is shown in Equation 2:

$$
z=\frac{0.266 \times 0.282}{\sqrt{0.070 \times 0.003+0.079 \times 0.005}}=3.4
$$

The results in Table 4 show that park management has a significant effect on tourist satisfaction without a mediator. By adding the mediator, the effect of park management is reduced, although it continues to exert a substantial direct effect on tourist satisfaction. The $\mathrm{Z}$ value is greater than 1.96 , which means that the indirect effect of park management on tourist satisfaction in the research model is significant. Consequently, environmental issues partially mediate the relationship between park management and tourist satisfaction. For Kinabalu Park, the investigation of the relationship between park management, environmental issues, and tourist satisfaction is important for future planning, management, and the implementation of tourism programs or activities.

Table 4. The result of mediating effect tests

\begin{tabular}{llcccc}
\hline \multicolumn{1}{c}{ Hypotheses } & Std.Beta & SE & $\begin{array}{c}\text { Type of } \\
\text { mediation }\end{array}$ & Z \\
\hline $\begin{array}{l}\text { Park management Tourist } \\
\text { satisfaction without mediator }\end{array}$ & $\rightarrow$ & 0.765 & 0.62 & & \\
$\begin{array}{l}\text { Park management Tourist } \\
\text { satisfaction with mediator }\end{array}$ & $\rightarrow$ & 0.699 & 0.081 & Partial & 3.4 \\
\hline
\end{tabular}

As a world class recognized biodiversity hotspots, this assessment is necessary to: (a) measure tourist satisfaction, and (b) understand the experience and opinion of tourists with respect to the management of the park and environmental issues. Tables 3 and 4 present an overview of the results of hypothesis testing. Based on 351 responses, this analysis confirms the relationships described in each of the research hypotheses.

The first and second hypotheses describe the effects of park management on tourist satisfaction and environmental issues. The results show that park management has a substantial and positive influence on environmental 
issues and tourist satisfaction. Visitors indicated a belief that effective park management was important for environmental and tourist satisfaction. Tourists specifically emphasized the importance of having effective park management strategies related to environmental issues. Participants agreed that each of the proposed park management strategies played an important role in conserving the ecosystem and increasing tourist satisfaction. These park management strategies include the implementation of a carrying capacity policy and establishing standards for development, establishing conflict resolution strategies and zoning for multiple uses, increasing knowledge and awareness through education and communication campaigns, broader management of tourist activities, and more effective enforcement of park rules and regulations. Testing the third hypothesis (re: the effects of environmental issues on tourist satisfaction) showed a positive result. The development of ecotourism and promotion of environmental issues plays an important role in improving tourist satisfaction in Kinabalu National Park. The literature would suggest that ecotourism and environmental issues exert a positive effect on tourist satisfaction (Benedetto et al., 2016). Testing the fourth hypothesis involved analyzing the indirect effects of park management and tourist satisfaction, using environmental issues as a mediating role. This fourth hypothesis was partly supported. This result indicates that the management of Kinabalu National Park needs to take a more active role in every aspect of the park's environmental conservation and ecotourism development if it is to actively promote tourist satisfaction. Wilderness destinations with better park management and planning strategies tend to be much more effective in attracting international tourism (Getzner et al., 2014).

Therefore, a renewed focus on environmental issues and ecotourism development in Kinabalu National Park should result in improved tourist satisfaction. This idea is consistent with argument extended by Inglis et al. (2005), that park management strategies should be designed to fulfil multiple objectives in terms of attracting new visitors and new residents, while simultaneously promoting conservation, thus supporting sustainable tourism development.

\section{CONCLUDING REMARK}

The findings of this study lead us to recommend that key stakeholders be incorporated in the future planning and management of the park. Park management should be prepared to consider the implementation of new policies and practices aimed at addressing various environmental issues and tourist satisfaction. To this end, park management should look beyond traditional approaches and seek input from subject expertise in order to develop a revised strategic management model for park management. As such, visitor activities 
Normah Abdul Latip, Rehmat Karim, Mastura Jaafar, Azizan Marzuki, A. Ghafar Ahmad, Sharifah Zahhura Syed Abdullah, Mohd Umzarulazijo Omar@Umar

Kinabalu National Park, Unesco World Heritage Site: Assessment of Environmental Issues, Tourist

Satisfaction and Park Management

should aim to ensure a negligible environmental impact. In addition, visitors should be educated and informed as to the park's rules ahead of visiting protected areas, thus promoting the protection of the park's original integrity and value. Ideally, tourist behaviors and activities will have a positive impact on maintaining the environmental.

\section{ACKNOWLEDGEMENTS}

The authors would like to acknowledge Universiti Sains Malaysia for providing the Research University Grants (RU), Grant No: 1001/PPBGN/8016051 as financial support to conduct this research.

\section{REFERENCES}

Abdul Latip, N., Badarulzaman, N., Marzuki, A., \& Umar, M. U. (2013). Sustainable Forest Management in Lower Kinabatangan, Sabah: Issues and Current Practices. PLANNING MALAYSIA JOURNAL, 11(3), 59-84. http://dx.doi.org/10.21837/pmjournal.v11.i3.108

Abdul Latip, N., Jaafar, M., Marzuki, A., Roufechaei, K. M., Umar, M. U., \& Karim, R. (2020). The Impact Of Tourism Activities On The Environment Of Mount Kinabalu, Unesco World Heritage Site. Planning Malaysia, 18(14). Retrieved from https://doi.org/10.21837/pm.v18i14.841

Azam, M., Mahmudul Alam, M., \& Haroon Hafeez, M. (2018). Effect of tourism on environmental pollution: Further evidence from Malaysia, Singapore and Thailand. Journal of Cleaner Production, 190, 330-338. https://doi.org/10.1016/j.jclepro.2018.04.168

Benedetto, G., Carboni, D., \& Corinto, G. L. (2016). Governance of sustainable tourism in a vast area surrounding a national park. Procedia Environmental Sciences, 32, 38-48. https://doi.org/10.1016/j.proenv.2016.03.010

Bennett, N. J., \& Dearden, P. (2014). Why local people do not support conservation: Community perceptions of marine protected area livelihood impacts, governance and management in Thailand. Marine policy, 44, 107-116. https://doi.org/10.1016/j.marpol.2013.08.017

Blanke, J., \& Chiesa, T. (Eds.). (2013). The Travel and Tourism Competitiveness Report 2013. Retrieved from http://www3.weforum.org/docs/WEF_TT_Competitiveness_Report_2013.pdf

Chin, W. W. (2010). How to write up and report PLS analyses. In V. Esposito Vinzi, W. W. Chin, J. Henseler, \& H. Wang (Eds.), Handbook of Partial Least Squares (pp. 655-690). https://doi.org/10.1007/978-3-540-32827-8 29

Getzner, M., Vik, M. L., Brendehaug, E., \& Lane, B. (2014). Governance and management strategies in national parks: Implications for sustainable regional development. International Journal of Sustainable Society, 6(1/2), 82. https://doi.org/10.1504/IJSSOC.2014.057891 
Hair, J. F., Ringle, C. M., \& Sarstedt, M. (2011). PLS-SEM: Indeed a Silver Bullet. Journal of Marketing Theory and Practice, 19(2), 139-152. https://doi.org/10.2753/MTP1069-6679190202

Inglis, J., Pearlman, M., \& Whitelaw, P. (2005). Best practice in strategic park management: Towards an integrated park management mode. Gold Coast, Australia: CRC for Sustainable Tourism. https://sustain.pata.org/wpcontent/uploads/2014/12/Inglis_ParkMgtModel.pdf

Jimura, T. (2011). The impact of world heritage site designation on local communities A case study of Ogimachi, Shirakawa-mura, Japan. Tourism Management, 32(2), 288-296. https://doi.org/10.1016/j.tourman.2010.02.005

Latip, N. A., Rasoolimanesh, S. M., Jaafar, M., Marzuki, A., \& Umar, M. U. (2018). Indigenous residents' perceptions towards tourism development: a case of Sabah, Malaysia. Journal of Place Management and Development. https://doi.org/10.1108/JPMD-09-2017-0086

Preacher, K. J., \& Hayes, A. F. (2008). Asymptotic and resampling strategies for assessing and comparing indirect effects in multiple mediator models. Behavior Research Methods, 40(3), 879-891. https://doi.org/10.3758/BRM.40.3.879

Rabbany, Md. G., Afrin, S., Rahman, A., Islam, F., \& Hoque, F. (2013). Environmental effects of tourism. American Journal of Environment, Energy and Power Research, 1(7), 117-130. Retrieved from https://www.researchgate.net/publication/348234496

Sobel, M. E. (1982). Asymptotic confidence intervals for indirect effects in structural equation models. Sociological Methodology, 13, 290-312. https://doi.org/10.2307/270723

Tay, K. X., Chan, J. K. L., Vogt, C. A., \& Mohamed, B. (2016). Comprehending the responsible tourism practices through principles of sustainability: A case of Kinabalu Park. Tourism Management Perspectives, 18, 34-41. https://doi.org/10.1016/j.tmp.2015.12.018

Received: $5^{\text {th }}$ November 2021. Accepted: $5^{\text {th }}$ December 2021 